\title{
Assessment of the Antimicrobial Effect of Honey, Treated By Heat and Ultraviolet Radiation
}

\author{
Nicodim Iosif FIŢ ${ }^{1}$ *, Flore CHIRILA $\breve{~}^{1}$, George NADĂŞ ${ }^{1}$, Octavian NEGREA ${ }^{1}$, Otilia BOBIŞ ${ }^{1}$, Liviu \\ MĂRGHITAŞ ${ }^{1}$
}

${ }^{1}$ University of Agricultural Sciences and Veterinary Medicine Cluj-Napoca, Faculty of Veterinary Medicine, 3-5 Mănăştur Street, 400372, Romania

*Corresponding author e-mail: nfit@usamvcluj.ro

Bulletin UASVM Veterinary Medicine 71(2) / 2014,

Print ISSN 1843-5270; Electronic ISSN 1843-5378

DOI:10.15835/buasvmcn-vm: 10738

\begin{abstract}
Honey bees are the main product being widely used by humans as food and as medicine. Honey is widely used in food, being highly appreciated in the traditional medicine. It also has important applications in natural feeding and pre-post-operative treatments in pediatric, dermatology and gastrology. In this paper we aimed to test the antibacterial effect of some types of honey treated by heat and ultraviolet radiation (UV).

For the experiment we used four types of honey (polyfloral, lime, acacia and sunflower) harvested from Salaj county. The antibacterial effect was tested on 11 strains of Staphylococcus spp., one stain of Staphylococcus aureus ATCC 6538P, Bacillus cereus strain ATCC 14579, Escherichia coli ATCC 10536 one, and a Pseudomonas aeruginosa ATCC 27853. After the heat treatment, test method was represented by the diffusion of the samples according to the CLSI (2011), adapted to the product. The antimicrobial effect of honey treated with UV was achieved by mixing honey and maintenance of microbial strains to UV for 1 hour and then determining the number of live bacteria expressed in colony forming units (CFU). For both test and control, samples were used without heat treatment or by UV and the results compared to the control. Tests to identify chemical compounds that degrade after these treatments were also performed.

After the examination of the results, it was observed that at 70 and $100^{\circ} \mathrm{C}$ honey treatment reduced the antimicrobial effect of honey with about half on most microbial strains. It was also found that temperatures of 70 and $100^{\circ} \mathrm{C}$ affect differently depending on the type of honey and tested strain. Temperature of 37 and $50^{\circ} \mathrm{C}$ does not diminish the antibacterial effect of honey. The chemical analyzes revealed an increase of HMF's high heat treatment. UV-decreased the amount of HMF in honey diastase index decreasing after heat treatment and increasing following treatment with ultraviolet (UV) radiation, while the carbohydrates in honey have undergone significant changes after heat and ultraviolet treatment.The experiment offers some interesting new data on the effect of two types of treatments in order to obtain honey types with standardized parameters.
\end{abstract}

Keywords: antimicrobial effect, honey, heat treatment, ultraviolet treatment

\section{INTRODUCTION}

It is known since ancient times that honey was used to treat many diseases especially surface lesions such as ulcers, burns, wounds and other superficial infections. This inhibits the growth of bacteria and fungi. The antibacterial effect of honey, mainly in case of Gram-positive bacteria is well documented. Both bactericidal and bacteriostatic effects have been reported for several strains, many of which are pathogenic
(Dezmirean and Mărghitaş, 2007; Aococx 1962, Zumi and Clayey, 1989).

The antimicrobial effect of honey is given by various components and depends on botanical origin, that is very diverse, depending on where it is produced. Using honey especially in traditional medicine lead to the investigation of honey benefits. This has proved that strawberry tree honey (Arbutus unedo) of Sardinia has valuable therapeutic property and Indian lotus 
honey (Nelumbium sceciosum) is said to be a good medicine for eye disease (Molan, 1992; Protea, 1989). Due to the fact that honey is a natural product containing varying amounts of enzymes, the treatment with heat or radiation involves different chemical and biological degradation of honey (White et al., 1963).

In the present study we aimed to evaluate the antibacterial effect of honey heat and UV light treated and biochemical changes occurring after these treatments.

\section{MATERIALS AND METHODS}

In order to conduct experiments we used four honey sorts (polyfloral, lime, acacia and sunflower) harvested in Romita, a town of Salaj county. Honey was extracted by centrifugation, having nutritional value of $3150 \mathrm{cal} / \mathrm{kg}$.

For the experiments tests were carried out on 10 strains of Staphylococcus spp. isolated from pyoderma lesions in dogs and Staphylococcus aureus ATCC 6538p. Other Gram positive and Gram negative strains such as Bacillus cereus ATCC 14579, Escherichia coli ATCC 10536 and Pseudomonas aeruginosa ATCC 27853 were also used in the experiment.

To test the antibacterial effect, honey samples were distributed in small containers $(2 \mathrm{ml})$, and then maintained at different temperatures $(37,50$, 70 , and $100^{\circ} \mathrm{C}$ ) for 30 minutes. The evaluation of antibacterial effect was performed by disc diffusion method using filter paper discs soaked in honey and placed over microbial culture at the density of 0.5 McFarland, dispersed in Mueller-Hinton agar plate. The interpretation was performed at 24 hours after incubation at $37^{\circ} \mathrm{C}$ and expressed in $\mathrm{mm}$ inhibition area diameter.

The assessment of antimicrobial effect of honey treated with UV radiation were used the same four types of honey. These sorts, in a thin film were exposed to UV radiation in the wavelength range of $254 \mathrm{~nm}$ for one hour. Subsequently, the treated and untreated samples of honey were mixed in equal volumes with microbial cultures to $0.5 \mathrm{McF}$ arland in saline. Antimicrobial effect of the UV-treated honey was carried out by determining the number of viable bacteria (CFU/ml) streaking the treated and untreated honey with UV at $37^{\circ} \mathrm{C}$ for 24 hours.

Biochemical alterations induced in treated honey were made by analyzing each type of sample heat and UV treated. For this evaluation, analysis were performed to highlight the deterioration compounds that honey releases and mostly hydroxymethylfurfural concentration determined by HPLC, diastatic index and the amount of sugars (fructose, glucose, sucrose, turanose, maltose, trehalose, isomaltase, erlose, fructose/glucose ratio, the amount of carbohydrates).

\section{RESULTS AND DISCUSSIONS}

After testing the 10 strains of staphylococci, the following results were observed (Table 1 ):

$100{ }^{\circ} \mathrm{C}$ inhibits the antimicrobial effect to most types of honey; there is still a situation in which the antimicrobial effect is still active at this temperature. This was observed in half of the tested microbial strains and particularly acacia and sunflower honey.

Tab. 1. Diameter of inhibition areas (in $\mathrm{mm}$ ) for 10 strains of staphylococci for heat treated honey samples.

\begin{tabular}{|c|c|c|c|c|c|c|c|c|c|c|c|c|c|c|c|c|}
\hline \multirow{3}{*}{$\begin{array}{c}\text { Staphylococcus } \\
\text { spp. Strain } \\
\text { number }\end{array}$} & \multicolumn{16}{|c|}{ Honey sorts } \\
\hline & \multicolumn{4}{|c|}{ Polyfloral honey } & \multicolumn{4}{|c|}{ Lime honey } & \multicolumn{4}{|c|}{ Acacia honey } & \multicolumn{4}{|c|}{ Sun flower honey } \\
\hline & $37^{\circ} \mathrm{C}$ & $50^{\circ} \mathrm{C}$ & $70^{\circ} \mathrm{C}$ & $100^{\circ} \mathrm{C}$ & $37^{\circ} \mathrm{C}$ & $50^{\circ} \mathrm{C}$ & $70^{\circ} \mathrm{C}$ & $100^{\circ} \mathrm{C}$ & $37^{\circ} \mathrm{C}$ & $50^{\circ} \mathrm{C}$ & $70^{\circ} \mathrm{C}$ & $100^{\circ} \mathrm{C}$ & $37^{\circ} \mathrm{C}$ & $50^{\circ} \mathrm{C}$ & $70^{\circ} \mathrm{C}$ & $100^{\circ} \mathrm{C}$ \\
\hline 1. & 9 & 8 & 8 & 8 & 7 & 11 & 7 & 7 & 7 & 8 & 7 & 7 & 12 & 10 & 8 & 8 \\
\hline 2. & 8 & 12 & 8 & 8 & 8 & 12 & 7 & 0 & 7 & 0 & 7 & 7 & 12 & 7 & 7 & 8 \\
\hline 3. & 7 & 15 & 9 & 8 & 14 & 12 & 10 & 0 & 7 & 7 & 7 & 7 & 20 & 12 & 8 & 0 \\
\hline 4. & 11 & 9 & 7 & 0 & 7 & 7 & 8 & 0 & 9 & 9 & 11 & 7 & 7 & 8 & 7 & 7 \\
\hline 5. & 8 & 9 & 7 & 8 & 8 & 8 & 7 & 0 & 8 & 9 & 8 & 7 & 12 & 11 & 7 & 7 \\
\hline 6. & 9 & 11 & 9 & 0 & 9 & 7 & 8 & 0 & 11 & 9 & 11 & 7 & 18 & 7 & 8 & 0 \\
\hline 7. & 12 & 10 & 9 & 9 & 8 & 12 & 14 & 10 & 9 & 8 & 11 & 9 & 16 & 13 & 13 & 8 \\
\hline 8. & 8 & 12 & 10 & 8 & 16 & 10 & 12 & 0 & 8 & 10 & 9 & 8 & 14 & 10 & 12 & 8 \\
\hline 9. & 8 & 8 & 9 & 0 & 9 & 14 & 12 & 8 & 8 & 9 & 7 & 7 & 15 & 9 & 11 & 8 \\
\hline 10. & 7 & 8 & 8 & 0 & 14 & 12 & 10 & 7 & 7 & 7 & 7 & 7 & 22 & 9 & 14 & 0 \\
\hline
\end{tabular}


Tab. 2. Diameter of inhibition areas (in $\mathrm{mm}$ ) for four honey sorts heat treated, on 4 ATCC strains.

\begin{tabular}{|c|c|c|c|c|c|c|c|c|c|c|c|c|c|c|c|c|}
\hline & \multicolumn{16}{|c|}{ Honey sorts } \\
\hline & \multicolumn{4}{|c|}{ Polyfloral honey } & \multicolumn{4}{|c|}{ Lime honey } & \multicolumn{4}{|c|}{ Acacia honey } & \multicolumn{4}{|c|}{ Sun flower honey } \\
\hline & $37^{\circ} \mathrm{C}$ & $50^{\circ} \mathrm{C}$ & $70^{\circ} \mathrm{C}$ & $100^{\circ} \mathrm{C}$ & $37^{\circ} \mathrm{C}$ & $50^{\circ} \mathrm{C}$ & $70^{\circ} \mathrm{C}$ & $100^{\circ} \mathrm{C}$ & $37^{\circ} \mathrm{C}$ & $50^{\circ} \mathrm{C}$ & $70^{\circ} \mathrm{C}$ & $100^{\circ} \mathrm{C}$ & $37^{\circ} \mathrm{C}$ & $50^{\circ} \mathrm{C}$ & $70^{\circ} \mathrm{C}$ & $100^{\circ} \mathrm{C}$ \\
\hline $\begin{array}{c}\text { Staphylococcus } \\
\text { aureus ATCC } \\
1245\end{array}$ & 11 & 9 & 0 & 0 & 7 & 8 & 10 & 0 & 9 & 11 & 8 & 7 & 7 & 8 & 6 & 0 \\
\hline $\begin{array}{c}\text { Bacillus cereus } \\
\text { ATCC } 14579\end{array}$ & 7 & 7 & 0 & 0 & 7 & 7 & 7 & 0 & 6 & 6 & 6 & 0 & 6 & 6 & 6 & 0 \\
\hline $\begin{array}{c}\text { Escherichia } \\
\text { coli ATCC } \\
10536,\end{array}$ & 9 & 10 & 10 & 6 & 8 & 10 & 12 & 6 & 8 & 12 & 12 & 8 & 9 & 11 & 8 & 8 \\
\hline $\begin{array}{c}\text { Pseudomonas } \\
\text { aeruginosa } \\
\text { ATCC } 27853\end{array}$ & 8 & 10 & 10 & 6 & 13 & 11 & 8 & 7 & 8 & 12 & 12 & 8 & 7 & 8 & 7 & 7 \\
\hline
\end{tabular}

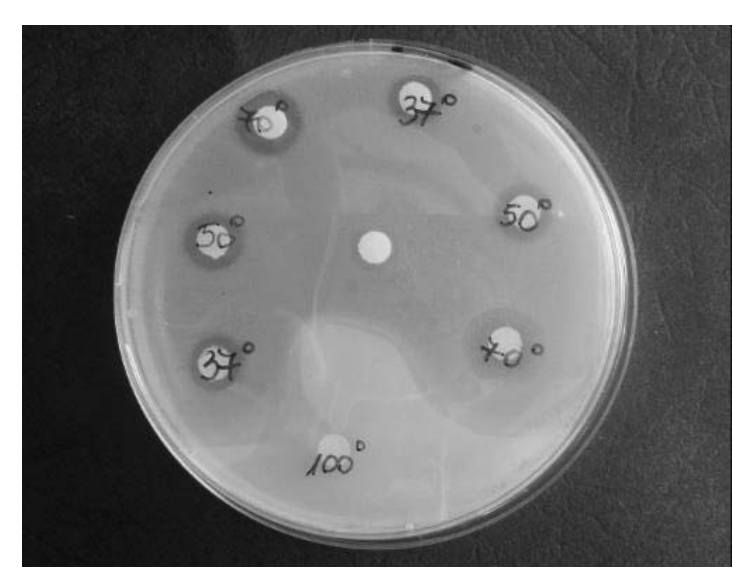

Fig. 1. Antibacterial effect of heat-treated honey (polyfloral and lime) on ATCC Escherichia coli 10536 strain

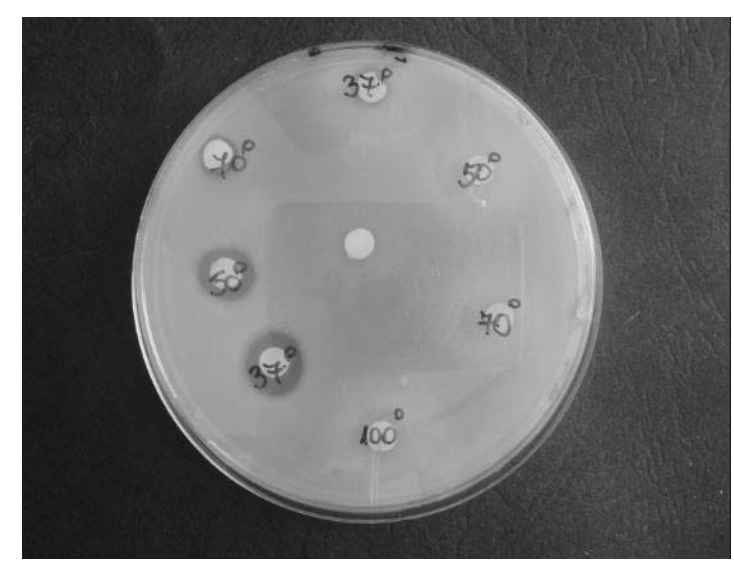

Fig. 3. Antibacterial effect of heat-treated honey (polyfloral and lime) on ATCC Pseudomonas aeruginosa 27853 strain

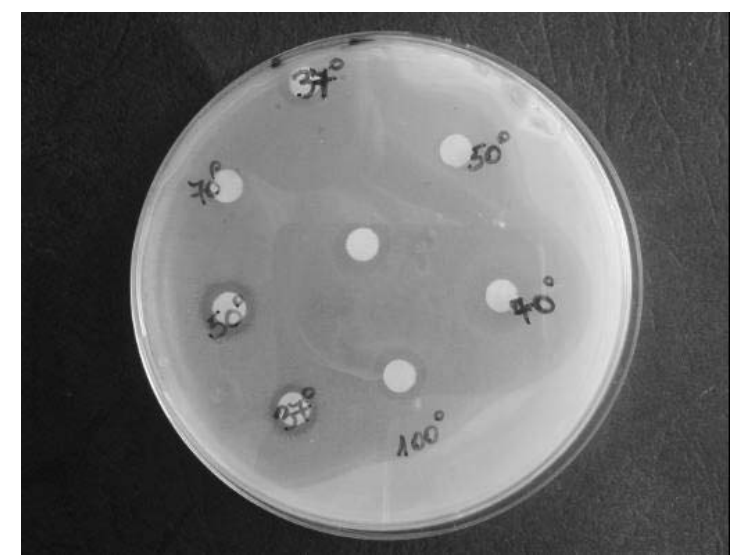

Fig. 2. Antibacterial effect of heat-treated honey (acacia and sunflower) on ATCC Escherichia coli 10536 strain

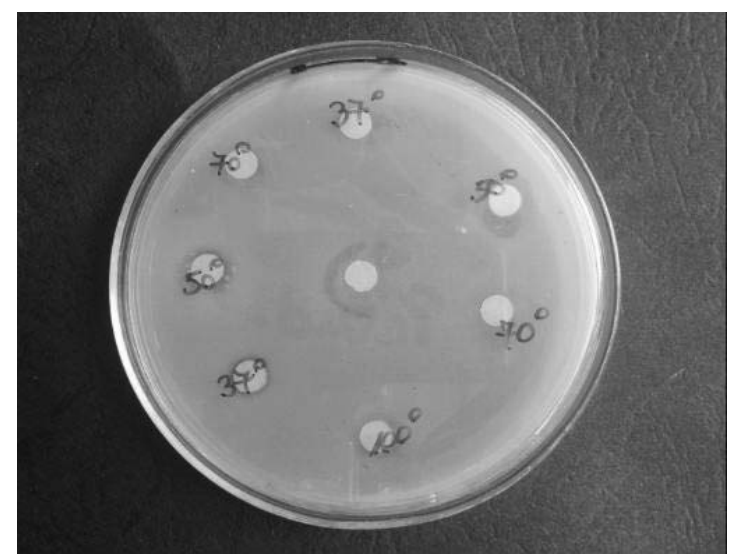

Fig. 4. Antibacterial effect of heat-treated honey (acacia and sunflower) on ATCC Pseudomonas aeruginosa 27853 strain 
Tab. 3. CFU/ml values of ATCC S. aureus 1245 and B. cereus 14579 strains tested with four UV treated honey sorts

\begin{tabular}{ccccc}
\hline & \multicolumn{2}{c}{$\begin{array}{c}\text { Staphylococcus aureus ATCC } \\
\mathbf{1 2 4 5}\end{array}$} & \multicolumn{2}{c}{$\begin{array}{c}\text { Bacillus cereus ATCC } \\
\mathbf{1 4 5 7 9} \\
\text { CFU/ml }\end{array}$} \\
\cline { 2 - 5 } Honey sorts & \multicolumn{2}{c}{ CFUl } & \multicolumn{2}{c}{ CFU } \\
& CFU/ml & CFU/ml in UV & CFU/ml & CFU/ml in \\
& 21682 & 17231 & 32428 & 26069 \\
\hline Polyfloral & 17867 & 16341 & 20347 & 13670 \\
Lime & 32364 & 22127 & 17803 & 13988 \\
Acacia & 15641 & 12526 & 25624 & 15387 \\
Sunflower & & & &
\end{tabular}

Tab. 4. Test results for hydroxymethylfurfural determination in heat-treated honey samples

\begin{tabular}{ccc}
\hline Sample & Heat-treatment in ${ }^{\mathbf{0}} \mathbf{C}$ & Hidroximetilfurfuralul (HMF) $\mathbf{~ m g} / \mathbf{k g}$ \\
\hline Polyfloral honey & 100 & 12.33 \\
Polyfloral honey & 70 & 3.95 \\
Polyfloral honey & 50 & 3.93 \\
Polyfloral honey & 37 & 3.81 \\
Lime honey & 100 & 6.52 \\
Lime honey & 70 & 2.44 \\
Lime honey & 50 & 2.52 \\
Lime honey & 37 & 2.55 \\
Acacia honey & 100 & 11.23 \\
Acacia honey & 70 & 4.87 \\
Acacia honey & 50 & 4.83 \\
Acacia honey & 37 & 4.64 \\
Sunflower honey & 100 & 20.53 \\
Sunflower honey & 70 & 4.51 \\
Sunflower honey & 50 & 5.98 \\
Sunflower honey & 37 & 5.59 \\
\hline
\end{tabular}

As can be observed from the table, heat treated honey for 10 strains of Staphylococcus spp. had the best effect at a temperature of $37^{\circ} \mathrm{C}$. There are some inhibition areas observed for the samples treated at $50^{\circ} \mathrm{C}$, likely due to increased diffusion capacity of the honey into the culture medium.

It was observed that staphylococci strains were sensitive in different manners to heattreated honeys, these aspects being observed and recorded by different results from the ten strains tested.

The results of heat-treated honey, on four ATCC bacterial strains, are presented in Table 2 .

Tab. 5. UV treated and hidroximetilfurfural results for honey types

\begin{tabular}{ccc}
\hline Honey type & Treatment & $\begin{array}{c}\text { Hidroximetilfurfural } \\
\text { (HMF) } \mathbf{~ m g / k g}\end{array}$ \\
\hline Polyfloral & U.V & 2,83 \\
Lime & U.V & 2,58 \\
Acacia & U.V & 4,61 \\
Sunflower & U.V & 5,13 \\
\hline
\end{tabular}

The evaluation of inhibition areas reveal that the best antimicrobial effect was obtained for B. cereus

Tab. 6. Diastatic index in heat treated honey sorts

\begin{tabular}{ccc}
\hline Sample & $\begin{array}{c}\text { Heat } \\
\text { treatment } \\
\text { in }{ }^{\mathbf{0}} \text { C }\end{array}$ & $\begin{array}{c}\text { Diastatic Indice } \\
\text { (DN) }\end{array}$ \\
\hline Polyfloral honey & 100 & 1.400 \\
Polyfloral honey & 70 & 6.854 \\
Polyfloral honey & 50 & 7.622 \\
Polyfloral honey & 37 & 7.056 \\
Lime honey & 100 & 2.016 \\
Lime honey & 70 & 15.631 \\
Lime honey & 50 & 12.914 \\
Lime honey & 37 & 14.752 \\
Acacia honey & 100 & 1.400 \\
Acacia honey & 70 & 8.632 \\
Acacia honey & 50 & 8.652 \\
Acacia honey & 37 & 8.571 \\
Sunflower honey & 100 & 1.521 \\
Sunflower honey & 70 & 9.439 \\
Sunflower honey & 50 & 11.076 \\
Sunflower honey & 37 & 10.753 \\
\hline
\end{tabular}


Tab. 7. Diastatic index in UV treated honey sorts

\begin{tabular}{ccc}
\hline Honey type & Treatment & Diastatic index \\
\hline Polyflower & U.V & 7,643 \\
Lime & U.V & 13,055 \\
Acacia & U.V & 18,873 \\
Sunflower & U.V & 18,732 \\
\hline
\end{tabular}

ATCC 14579strain, the other strains showing a moderate sensitivity.

The antibacterial activity differently decreases depending on the temperature. At 70 and $100^{\circ} \mathrm{C}$ the activity is visible decreasing on all four types of honey as best observed in strains of $E$. coli and Pseudomonas aeruginosa (Fig. 1, 2, 3 and 4).

After testing four types of honey treated with UV radiation on Staphylococcus aureus ATCC 1245 and Bacillus cereus ATCC 14579 we can observe that UV radiation decreased the number of bacteria in honey samples, but not as much as UV untreated control samples (Table 3).

Biochemical analyzes result for hydroxymethylfurfural determination in honey samples show that its amount increases with temperature (Table 4).
For UV treated honey, the value is lower in all four honey sorts, comparative to heat treated honey. Thus in Table 5 it can be seen that the lower value of this index is 2.58 for lime honey and the largest for sunflower honey - 5.13 (Table 5).

Analyses performed on heat-treated honey diastase index are presented in Table 6 and show that its value is different between types of honey, decreasing after treatment at $100^{\circ} \mathrm{C}$ below 2.0, which means that the enzymes are denatured at this temperature below the limit of STAS $784 / 1 / 2009$, which are at least 6.5.

Also it appears that the diastatic index is higher after treatment with UV honey reaching 18.732 for sunflower honey, 18.873 for acacia and 13.05 for lime honey.

Overall the acacia honey and sunflower UV doubles diastatic index value and for polyfloral honey the amount increases compared to heat treated honey (Table 7).

Analyses performed on carbohydrates amount in honey samples heat treated are shown in Table 8. In the table it can be seen that the amount of

Tab. 8. Sugar amounts in heat treated honey sorts (\%)

\begin{tabular}{ccccccccccc}
\hline $\begin{array}{c}\text { Heat } \\
\text { treatment }\end{array}$ & Fructose & Glucose & Sucrose & Turanose & Maltose & Trehalose & Isomaltose & Erlose & $\begin{array}{c}\text { fructose/ } \\
\text { glucose index }\end{array}$ & Sugars \\
\hline 100 & 41.3 & 25.42 & 0.62 & 2.64 & 1.53 & 0.73 & 0.7 & 1.94 & 1.62 & $\mathbf{7 4 . 8 8}$ \\
70 & 41.38 & 24.66 & 0.61 & 2.67 & 1.55 & 0.73 & 0.7 & 1.93 & 1.68 & $\mathbf{7 4 . 2 3}$ \\
50 & 41.21 & 24.56 & 0.58 & 2.63 & 1.52 & 0.72 & 0.76 & 1.88 & 1.68 & $\mathbf{7 3 . 8 6}$ \\
37 & 42.22 & 25.28 & 0.59 & 2.71 & 1.54 & 0.74 & 0.7 & 1.94 & 1.67 & $\mathbf{7 5 . 7 2}$ \\
100 & 38.25 & 30.29 & 0.07 & 2.25 & 1.5 & 0.98 & 0.96 & 0.45 & 1.26 & $\mathbf{7 4 . 7 5}$ \\
70 & 37.88 & 29.32 & 0.12 & 2.25 & 1.36 & 0.9 & 0.76 & 0.34 & 1.29 & $\mathbf{7 2 . 9 3}$ \\
50 & 39.47 & 27.54 & 0.12 & 2.38 & 1.37 & 0.94 & 0.83 & 0.36 & 1.43 & $\mathbf{7 3 . 0 1}$ \\
37 & 38.58 & 29.99 & 0.12 & 2.28 & 1.35 & 0.92 & 0.75 & 0.35 & 1.29 & $\mathbf{7 4 . 3 4}$ \\
100 & 42.92 & 25.41 & 0.53 & 2.76 & 1.79 & 0.7 & 0.5 & 2.13 & 1.69 & $\mathbf{7 6 . 7 4}$ \\
70 & 43.76 & 25.92 & 0.61 & 2.8 & 1.72 & 0.74 & 0.52 & 2.15 & 1.69 & $\mathbf{7 8 . 2 2}$ \\
50 & 43.56 & 25.73 & 0.64 & 2.83 & 1.78 & 0.7 & 0.54 & 2.16 & 1.69 & $\mathbf{7 7 . 9 4}$ \\
37 & 42.48 & 24.91 & 0.63 & 2.79 & 1.75 & 0.75 & traces & 1.7 & 1.71 & $\mathbf{7 5 . 0 1}$ \\
100 & 38.57 & 36.15 & traces & 0.72 & 0.58 & 0.26 & traces & traces & 1.07 & $\mathbf{7 6 . 2 8}$ \\
70 & 39.65 & 36.21 & traces & 0.75 & 0.71 & 0.2 & traces & traces & 1.10 & $\mathbf{7 7 . 5 2}$ \\
50 & 41.91 & 33.77 & traces & 0.79 & 0.69 & 0.22 & traces & traces & 1.24 & 77.38 \\
37 & 40.86 & 36.19 & traces & 0.78 & 0.7 & 0.21 & traces & traces & 1.13 & 78.74 \\
\hline
\end{tabular}

Tab. 9. Sugar amounts in UV treated honey sorts

\begin{tabular}{|c|c|c|c|c|c|c|c|c|c|c|}
\hline Honey sorts & Fructose & Glucose & Sucrose & Turanose & Maltose & Trehalose & Isomaltose & Erlose & $\begin{array}{c}\text { fructose/ } \\
\text { glucose index }\end{array}$ & Sugars \\
\hline Polyfloral & 42.58 & 25.45 & 0.63 & 2.73 & 1.62 & 0.72 & 0.63 & 1.9 & 1.67 & 76.26 \\
\hline Lime & 38.72 & 29.55 & 0.1 & 2.34 & 1.48 & 1.01 & 1.05 & 0.41 & 1.31 & 74.66 \\
\hline Acacia & 44.00 & 25.7 & 0.61 & 2.82 & 1.72 & 0.67 & 0.6 & 2.13 & 1.71 & 78.25 \\
\hline Sunflower & 39.72 & 36.95 & traces & 0.78 & 0.64 & 0.23 & traces & traces & 1.07 & 78.32 \\
\hline
\end{tabular}


sugars in honey samples is not visibly affected by heat treatment.

Treatment with UV honey did not significantly alter carbohydrate values that can be observed comparing the results in Table 8 and 9. It is found that sunflower and acacia honey have the highest percentage of sugars.

\section{CONCLUSIONS}

The antibacterial effect of the honey is not affected by heat treatment at 37 and $50^{\circ} \mathrm{C}$ for 30 minutes. Polyfloral honey varieties, lime, acacia and sunflower had a similar antibacterial effect, with small differences, sunflower honey highlighting the zones of inhibition greater than the other three varieties;

Maintenance of honey at 70 and $100^{\circ} \mathrm{C}$ for 30 min decreased the antibacterial effect of honey according to the honey sort and microbial strain tested;

UV light treatment of honey sorts resulted in an increase in the antimicrobial effect slightly reducing the number of germs;

Chemical analyzes performed on heattreated honey varieties showed an increase in hydroxymethylfurfural amount directly proportional to the heat treatment;

Diastatic index value in heat treated honey samples decreased in proportion to the intensity of the heat treatment, and for the samples UV treated diastase index increased.

Amount of sugars in honey samples heat treated with UV radiation did not vary significantly.

\section{REFERENCES}

1. Al-Waili NS. (2004). Investigating the antimicrobial activity of natural honey and its effects on the pathogenic bacterial infections of surgical wounds and conjunctiva. J. Med Food. 7(2):210-22.

2. Al-Waili NS ${ }^{1}$, Saloom KY, Akmal M, Al-Waili TN, Al-Waili AN, Al-Waili H, Ali A, Al-Sahlani K (2007). Effects of heating, storage, and ultraviolet exposure on antimicrobial activity of garlic juice. J. Med Food. 10(1):208-12.

3. Aococx, D (1962). The effect of catalase on the inhibine and peroxide values of various honeys. Journal of Apicultural Research 1: 38-40.

4. Dezmirean Daniel Severus, Marghitas Liviu Alexandru, (2007)., Tehnologii apicole speciale. Editura AcademicPress Cluj-Napoca, ISBN: 978-973-744-218-5.

5. Floris Prota, R. (1989). Sul miele amaro di Sardegna. Apicoltore Moderno 80(2): 55-67.

6. Peter C Molan, (1992). The Antibacterial Activity of Honey. Bee World Vol.73 (1) pp.5-28

7. White J W; Subers, M H; Schepartz, A I (1963) The identification of inhibine, the antibacterial factor In honey, as hydrogen peroxide and its origin in a honey glucoseoxidase system. Biochimica et Biophysica Acta 73: 57-70.

8. Zumi A, A; Luto, A (1989). Honey - a remedy rediscovered. Journal of the Royal Society of Medicine 82: 384-385. 